\title{
SRAFFA VERSUS KEYNES ON THE METHOD OF ECONOMICS: MEASUREMENT, HOMOGENEITY AND INDEPENDENCE
}

\author{
Anna Carabelli ${ }^{\star}$
}

\section{ABSTRACT}

The paper investigates the methodology Sraffa and Keynes apply in their critique of economic theories and the development of their own theory. The main focus is on their views on the measurement of economic magnitudes and the assumptions required. There are striking points of similarity in the methodology of their critique, but also contrasting approaches and divergences when they set about positively constructing their own new theory.

Keywords: J.M. Keynes, P. Sraffa, Economic Methodology, Economic Measurement. JEL codes: B31, B41.

I investigate the methodology Sraffa and Keynes apply in their critique of economic theories and the development of their own theory. ${ }^{1}$ The main focus is on their views concerning the measurement of economic magnitudes and the assumptions required. There are striking points of similarity in the methodology of their critique, but also contrasting approaches and divergences when they set about positively constructing their own new theory. I will consider both their published and unpublished writings.

^ Università del Piemonte Orientale. Address for correspondence: anna.carabelli@uniupo.it. I thank two anonymous referees for their valuable comments.

1 Here I use the terms 'method' and 'methodology' interchangeably, but the terms have different meanings. The former is used more to refer to technique and how concepts are used, applied, and developed. The latter refers to epistemology and the philosophy of science basis on which explanations are made. The ideas of objectivism/physicalism, rationalism, and empiricism are epistemological concepts. Heterogeneity, independence, etc. are method concepts. Here I make use of both meanings, because method and methodology are strictly connected, but the purpose of the paper is ultimately to examine the latter. 
My examination of Sraffa's manuscripts (held at Trinity College, Cambridge), which are less known to the general public, concentrates on the 1920-1930 period, which was contemporary with Keynes.

Sraffa read most of Keynes's published writings, including - surprisingly - some writings which I find relevant to this comparison. I do not know exactly how much Keynes knew of Sraffa's manuscripts which have now become available and are examined here. It is an established fact that they exchanged ideas, and Keynes certainly read or at any rate discussed some of the points under investigation in this paper. I have no evidence that Keynes actually read Sraffa's unpublished papers, apart from those to which I refer to later on. In 1928 Keynes and Pigou read a text written by Sraffa, which may be document D3/12/6 (in particular items 4, 6-7 and 9-15), covering more or less chapters 1 and 2 of Production of Commodities by Means of Commodities, where the model of a system with three commodities and surplus is investigated. A letter by Pigou to Sraffa dated January 1928 has survived (Sraffa C239).

Again, I have no evidence that Sraffa read or indeed knew of some of Keynes's manuscripts (held at King's College, Cambridge) now available to current readers, which have cast further light on Keynes's method. Keynes might have shown some of them to Sraffa. Among Sraffa's books we find three interesting items written by Keynes in 1908-1913: reprints of Keynes's "Board of Trade Index-Numbers of Real Wages", Economic Journal Dec. 1908 (Sraffa 4565); "Tables showing for each of the Years 1900-1911 the estimated value of the Import and Exports of the United Kingdom at the Prices prevailing in 1900”, Economic Journal, Dec. 1912 (Sraffa 4576) and Keynes's reviews of Barbour D. The standard of Value (1912) and Hobson J.A. Gold, Prices and Wages, (1913), Economic Journal, Sept. 1913 (Sraffa 4577). Furthermore, tucked into one of the two copies of Keynes's The End of Laissez-Faire (1926) in Sraffa's library (Sraffa 2661), - a copy which seems to have previously belonged to C. R. Fay - there is a loose sheet written by Keynes containing a list of Keynes's readings on "Averages and Laws of Error" ("Pigou, J.N.K, Norton, Berry, Johnson, Whitehead, Russell Kapteyn, Pearson, Edgeworth, Yule, Hardy, Richmond, Sanger").

I pay particular attention to Keynes's A Treatise on Probability (hence forth TP) (1921), which I consider his major work on method (Carabelli

2 I thank the Keynes Trustees and the Sraffa Trustees for permission to quote respectively from Keynes's manuscripts held in King's College Library, Cambridge, and Sraffa's manuscripts held in Wren Library, Trinity College, Cambridge. Books in Sraffa's library are indicated with brackets containing the number of the book under consideration as catalogued in Trinity College Library, Cambridge. I also thank the two anonymous referees for their useful comments and suggestions. 
1988). In particular, I do not know if Sraffa read the TP before 1925 . We know for a fact that by the end of 1928 Sraffa had carefully read, taken notes on and annotated his own copy of Keynes's A Treatise on Probability (Sraffa 2645), and in particular he had drafted separate notes on the "Appendix on Cause". In his own copy of A Treatise on Probability his annotations on the last page regard in particular the atomic character of natural law and legal atoms (TP: 249; CW 8: 278); dependence for knowledge and for causation (TP: 164-165; CW 8: 181-183); independent variety (TP: 251; CW 8: 279); Notes on Part III On the use of the term Cause (TP: 275-277; CW 8: 306-308).

As an exercise in comparison of methodologies, this paper does not investigate on whether Sraffa derived his negative methodological approach, i.e. his methodology of criticism, from Keynes's approach, or vice-versa. It simply argues that there are significant similarities on relevant points. Further, it argues that they moved in opposite directions when constructing their own theories; consequently, we find sharp contrast in their positive method.

Section 1 deals with Sraffa's and Keynes's views on the measurement of economic magnitudes. Section 2 deals with the two economists' criticism of the assumptions of homogeneity (2.1) and independence (2.2) in economic theory. Section 3 deals with Sraffa's and Keynes's constructive approach to economic theory, discussing Sraffa's search for a common physical unit of measure for aggregates and Keynes's adoption of money as measure. Section 4 concludes.

\section{SRaffa and Keynes on Measurement}

Both Sraffa's and Keynes's investigation into measurement starts with definitions of concepts. This procedure helps to avoid ambiguity and vagueness in expression, and the risk of adopting methods that beg the question, using words to which no definite concepts necessarily correspond.

In defining concepts to be used in science, one main problem is their quantitative measurement, be it numerical or ordinal. The concept of quantity itself is interrelated with that of measure. Measurement is to be understood at the theoretical level - i.e. from the point of the philosophy of measure - and not that of the actual measuring of magnitudes. Sraffa, like Keynes, was not interested in the difficulties involved in actually measuring quantities (the so-called statistical problems) but in the theoretical problems of measurement.

Their interest was in the existence of a unit of quantity which has characteristics relevant to the purposes of the theory chosen and of a unit (or 
standard) of measurement which is independent of the quantity to be measured. In particular, their attention was directed to the system as a whole and not to the individual elements - an attitude spelt out by Keynes ("the choice of the units of quantity appropriate to the problems of the economic system as a whole", CW 7: 37). Sraffa was further interested in enquiring as to whether these units are absolute.

Economic quantities can be expressed (measured) in value; not all economic quantities can be expressed (measured) in physical terms. Moreover, quantities can be expressed or measured in physical terms only under restricted conditions. In fact, when difficulties in their physical measurement arise, economists usually make recourse to value measures, either in price or in money terms. And yet, problems may also arise with value measures.

\subsection{Sraffa on Measurement}

In the 1950s, at the Corfu conference on capital theory, organised by the International Economic Association (4-11 September 1958) (Lutz and Hague 1961), Sraffa distinguished the requirements for theoretical measurement from those specific to statistical analysis. From the report of Sraffa's interventions in the discussion of Hicks' paper "The Measurement of Capital in relation to the Measurement of Other Economic Aggregates", ibid. pp. 18-31:

Mr Sraffa thought one should emphasize the distinction between two types of measurement. First, there was the one in which the statisticians were mainly interested. Second there was measurement in theory. The statisticians' measures were only approximate and provided a suitable field for work in solving index number problems. The theoretical measures required absolute precision. Any imperfections in these theoretical measures were not merely upsetting, but knocked down the whole theoretical basis. One could measure capital in pounds or dollars and introduce this into a production function. The definition in this case must be absolutely water-tight, for with a given quantity of capital one had a certain rate of interest so that the quantity of capital was an essential part of the mechanism. One therefore had to keep the definition of capital separate from the needs of statistical measurement, which were quite different. The work of J.B. Clark, Böhm-Bawerk and others was intended to produce pure definitions of capital, as required by their theories, not as a guide to actual measurement. If we found contradictions, then these pointed to defects in the theory, and an inability to define measures of capital accurately. It was on this - the chief failing of capital theory that we should concentrate, rather than on problems of measurement (Report of Sraffa's interventions in Lutz and Hague 1961: 305-306). ${ }^{3}$

3 See the full discussion: "Professor Hicks was not quite clear about this. Did Mr. Sraffa mean to equate models with theories? He could see that in a particular model one could only 


\section{According to the report, Sraffa went on to say that:}

The usefulness of any theory lay in its explanatory value [...]. [He] took the view that if one could not get the measures required by the theorists' definitions, this was a criticism of theory, which the theorists could not escape by saying that they hoped their theory would not often fail. If a theory failed to explain a situation, it was unsatisfactory (ibid.: 306).

In Production of Commodities Sraffa used the Standard commodity as the measuring yardstick. He constructed his concept of a Standard commodity in order to make visible the inverse relationship under specified conditions between the share of wages and the rate of profits. The use Sraffa made of the Standard commodity was to solve Ricardo's problem that the value of the surplus to be distributed varies with changes in the distribution itself between wages and profits: assuming that wages are paid at the end of the year there is a linear relationship between the share of wages in the surplus and the rate of profits.

In his manuscripts, Sraffa approved of Sidgwick's statement in his Principles that "the importance of seeking the best definitions" is far greater than "the importance of finding it". This was done by analysing the "Assumptions on which the theory of value is generally based" (Sraffa D1/20 3-4). Sraffa pointed out Sidgwick's statements on the "necessity of unit of measurement, not for measurement, but for conception" (D1/20 5) and stressed that "we must find a unit of measure for cost: the necessity for this unit arises, not from a desire of actually measuring, - it is prior to it, and is required even for thinking of cost" (D3/12/3 46). As we shall see, this attitude is similar to Keynes's. The differences between Sraffa and Keynes rest on the question of which magnitudes should to be taken into consideration in economic theory and which should not. In a note written in the Summer-October of 1929, Sraffa distinguished among three groups of quantities. I quote the whole passage:

1) Those which cannot possibly be measured, because they are not defined in terms of the method of measuring them, e.g. marg.[inal] utility and sacrifice. (No

make that model water-tight by introducing drastic simplifications. Only thus, for example, could one have a clear and precise definition of capital stock. But some simplifications were so drastic that he himself was not interested in any theory based on them. Mr. Sraffa replied that Wicksell's might be a simple model in that he worked out a simple and general theory for future development. Surely, the usefulness of any theory lay in its explanatory value. Was one only interested in a theory if one could fit actual figures into it; or was one interested independently of that? Professor Hicks argued that if a theory was to explain the working of the social mechanism, it ought to be capable of having measurable concepts fitted into it. Mr. Sraffa took the view that if one could not get the measures required by the theorists' definitions, this was a criticism of theory, which the theorists could not escape by saying that they hoped their theory would not often fail. If a theory failed to explain a situation, it was unsatisfactory". 
definition at all is given for measuring them in the case of several individuals: in the case of one individual, they are defined as being proportional to certain quantities, i.e. prices, but this is, as Cairnes says, "merely giving a name to the unknown causes of price".) Such quantities must be excluded altogether: at the worst, they may be used as a fictitious device for solving problems, but must not appear either in the premises nor in the conclusions.

The second group consists of those quantities which Sraffa believed that economic analysis should take into consideration:

2) At the opposite extreme there are quantities which can be, and in fact are, statistically measured. These quantities have an objective, independent existence at every or some instants of the natural (i.e. not interfered with by the experimenter) process of production and distribution; they can therefore be measured physically, with the ordinary instruments for measuring number, weight, time, etc. Such are quantities of various materials used or produced, of lands[,] quantities of labour (?), lengths of periods (?), etc. These are the only quantities which must enter as constants in economic theory, i.e. which can be assumed to be "known" or "given". [In parentheses he added: The "extensive" theory of rent, and the labour theory of value only assume this kind of knowledge].

Then there is a third group:

3) Finally, there is the class of quantities, which form the basis of Marshall's theory (or, rather, of Pareto's), such as demand \& supply curves, marginal productivities, (i.e. rate of growth of total) indifference curves, etc. Here the constant quantities have no names - they are the parameters of curves. The several quantities represented by these curves do not exist at any one moment, nor during any period of the recurrent steady process of production or consumption. They are alternatives, only one of which can exist in any one position of equilibrium, all the others being thereby excluded (even the one does not really exist if there is no change, since it is the rate of growth of a quantity, i.e. marginal product: it can be inferred from price, but so can marginal utility, which under (1) we have agreed does not exist). Therefore, they cannot be found by merely observing the process or state of things, and measuring the quantities seen. They can only be found out by means of experiments - and these quantities in effect are always defined in terms of such experiments (successive doses applied to land; alternatives offered to the consumer; etc.).

\section{He went on to point out that:}

These experiments cannot be carried out (and never have been, as a matter of fact) for various reasons, 1) the practical difficulties, 2) the lack of definition of the conditions to be required, which are always summed up in the absurd "other things being equal" (D3/12/13: 2-3, 5). 
For Sraffa economic magnitudes belong to group 2). They are concrete, tangible and visible; they can be physically measured, in number, weight (tons or gallons) and time. These quantities are the only ones that must enter as constants in economic theory, i.e. which can be assumed to be 'known' or 'given'. His concept of magnitudes and of their measurement was informed by the method of natural sciences, especially physics, mechanics and thermodynamics. This approach shaped his general conceptions about the method of economics and the nature of its subject matter. He was in favour of the 'objectivisation' (D3/12/7 46) of economics, accepting a materialist point of view and an empiricist epistemology. For him, the positivist method of hard sciences had to be applied to economics. For the development of science, there is one method, namely that of physics. The different disciplines, such as physics, biology, economics and psychology had to converge towards a scientific synthesis. He described his method as being concerned with establishing "an entirely objective point of view", a "natural science point of view" or "an atomic analysis" [D3/12/7: 161 (3); D3/12/13: $16(9), 18]$. Let us recall that the 1920s and 1930s of the last century were characterised by the dominance of the neo-positivism of the Vienna Circle and logical atomism.

As Kurz and Salvadori have shown (2005b: 425-426), in the second half of the 1920s Sraffa read books on physics, the natural scientists and neopositivist epistemology, in particular Hertz and Whyte. ${ }^{4}$ Sraffa also read and made notes on A.S. Eddington's 1927 Gifford Lectures on The Nature of the Physical World (Eddington 1928). In April 1928 he studied and again made notes on A. N. Whitehead's Science and the Modern World (Whitehead 1926). Kurz and Salvadori judge from Sraffa's annotations that he agreed to a large extent with Whitehead's materialism and with what he had to say on science becoming quantitative; he also subscribed to the search for measurable elements among phenomena. In my view Sraffa also shared Whitehead's empiricism. ${ }^{5}$ In November 1927 Sraffa read, among other texts, The Trend of Economics (Tugwell 1924), a collection edited by Rexford Tugwell of papers by leading American economists including F.H. Knight and J.M. Clark with the aim of reconsidering the method and content of economics in the light of developments in physics. Sraffa read the book, took notes on it and, according to Kurz and Salvadori (2005b), referred

4 Remarkably, Sraffa took notes on Heinrich Hertz's (1899) The Principles of Mechanics, focusing attention on the physicists' concepts, and in particular on 'cause' and 'interdependence'.

5 It is worthwhile to remember that Whitehead was one of the two referees of Keynes's 1907 Dissertation The Principles of Probability; his empiricism was one of the reasons for his rejection of Keynes's Dissertation, where an attack on the empiricist interpretation of probability (frequency) was launched. 
to it repeatedly in his papers (D3/12/11, dated November 1927). Knight denied that it was possible 'to construct in thought a world of real objects in purely objective terms' and that human phenomena were 'amenable to treatment in accordance with the strict canons of science' (Knight 1924: 242, 251). According to him 'it is impossible to discuss value in purely objective terms' (Knight 1924: 229). Kurz and Salvadori argue that Sraffa's notes show him disagreeing with Knight but concurring with some of the observations made by J. M. Clark, who advocated a fundamentally different point of view. ${ }^{6}$

\subsection{Keynes on Measurement}

Keynes's approach to the measurement of economic magnitudes was the opposite of Sraffa's. For him, economics is a moral science and economic magnitudes are not analogous to those of the physical sciences (CW 13: 299-300). Keynes explicitly criticised J.M. Clark's method and applied to economic magnitudes his philosophy of the measurement of probability (Keynes 1907, 1908, 1921; see Carabelli 1988; 1992, 1994).

In Chapter 3 of $A$ Treatise on Probability, Keynes tackles the logical and theoretical difficulties in the measurement of probability, and not the statistical-mathematical problems due to our inability to measure it. He raises the question of the existence of a measure of probability, i.e. the existence of a general or "'natural' unit of measure and of quantity" (CW 7: 33). His discussion is more relevant to theoreticians (be they economists or otherwise) than to applied scientists or statisticians: "That such comparison is theoretically possible, whether or not we are actually competent in every case to make the comparison, has been the generally accepted opinion" (CW 7: 21). The theoretical difficulty of numerical measurement is intrinsic and inherent in probability. We will see, how this difficulty is equally intrinsic and inherent in macroeconomic magnitudes and does not depend on our inability to measure them (CW 11: 52, 135). This intrinsic indeterminateness is stressed in A Treatise on Probability:

It is not the case here that the method of calculation, prescribed by theory, is beyond our powers or too laborious for actual application. No method of calculation, however impracticable, has been suggested. Nor have we any prima facie indications of the existence of a common unit to which the magnitudes of all

6 See also the recent debate on the meaning of Sraffa's objectivism/physicalism. Davis (2018) argues that Sraffa's 1931 'Surplus Product' paper (D3/12/7 161: August 1) shows him questioning his pre-1928 view, primarily because it eliminated the concept of a measurable surplus and was inconsistent with including the role that distribution played in determining commodity values. 
probabilities are naturally referrable $[\ldots]$ probabilities do not all belong to a single set of magnitudes measurable in terms of a common unit

(CW 7: 32-33, emphasis in original; on common unit see also 35-36).

For Keynes, the same difficulty arises in the case of nearly all the quantities dealt with by science:

There is no unique unit of measurement [...]. The ground of the element of arbitrariness in the unit of measurement of most physical quantities is easily explained. The objective quality measured does not really possess numerical quantitativeness, although it may possess some of the properties necessary for numerical quantitativeness [...]. In general, the values which it can assume are capable of being ranged in order of magnitude and, in addition, it will sometimes happen that the series which is thus formed is continuous, that is to say, for any two selected values there can be found a value whose order in the series is between the two selected values. But it does not follow from this that there is any meaning in the assertion that one value is twice another value. The relations of continuous order can exist between the terms of a series of values, without the relations of numerical quantitativeness existing at the same time. But we can nevertheless measure the values after a manner which is somewhat arbitrary but which yields results sufficiently satisfactory for many purposes, those, for instance, of mathematical physics, though not for those of probability. This method is to select some other quantity or ratio [...]. For instance, the series of values of the quantity measured by a specific volume have this relation $[\ldots]$ to a conventional measurement $[\ldots]$. The intervals which we regard as equal depend upon this arbitrary choice.

(Keynes 1907: 97-98, emphasis in original)

In his discussion of the measurement of probability in the first version of the Principles of Probability (1907), Keynes considered the current state of the philosophy of measurement and, in particular, of the measurement of relations. His main interest was in the "philosophy of magnitude", not in the mathematics of magnitude (Keynes 1907: 119; see also TP, CW 8: 37). He devoted particular attention to Russell's Principles of Mathematics (1903). The probability relation is a quantity (Keynes 1907: 52, CW 8: 21) in general, a non-numerical quantity. Keynes argues that a quantity is not necessarily a number, "the numerical view of probability is partly traceable to the frequent definition of probability as a number and not as a quantity" (Keynes 1907: 56). Only probability relations which are of the same kind and in the same unit of quantity are numerically measurable and therefore numerically comparable (ibid.: 62). Difficulties in finding a common unit of quantity arise when these quantities of probability are similar to quantities which may, at the same time, be characterized by a collection of attributes, such as a class of qualities rather than by one single quality: "the compari- 
son of the probability of such propositions as 'this book is red', and 'this book is blue'. By 'red' not one single quality is meant, but a class of qualities. The book is to have one out of a class of qualities which we may call 'the reds"' (Keynes 1907: 120).

Keynes distinguishes between non-comparable, comparable and numerically comparable probabilities. There are

three possible degrees of intimacy between the magnitudes of any pair of probabilities. Some cannot be compared at all in this respect; between others the relations of more or less can be established; and others again seem to be capable of numerical measurement in terms of some common unit (ibid.: 60-61).

This heterogeneity in kind and in the units of quantity depends on a multidimensionality of the magnitude of probability. "Yet the base units of the different strands (kinds of probability) are not altogether in different dimensions, as, for instance, are those of beauty and goodness" (ibid.: 65). Later, in his Treatise on Money, he became more radical as regards economic quantities, speaking of "things being $[\ldots]$ in different dimensions $[\ldots]$ and capable of variations of degree in more than one mutually incommensurable direction" (CW 5: 87-88).

The probability relation has an intrinsic quantitative indeterminateness. The impossibility of a numerical measurement of probability is not a product of mental incapacity or lack of knowledge, but arises from the nature of the case itself. This impossibility is "absolute and inherent in the subject matter" (Keynes 1907: 65) because there is no determinacy of the units of quantity. These units belong to different kinds of magnitudes.

\section{Sraffa's and Keynes's Methodology of Critique: Investigation into THE Assumptions of ECONOMIC TheORY}

In connection with the problem of the existence of units of quantity and measure necessary "for conception", we find Sraffa's and Keynes's investigation of the various logical requirements for measurement. Crucial among these requirements were the assumptions of homogeneity and independence. Again, there are close similarities between Sraffa and Keynes in these destruens approaches.

Sraffa builds his critique of Marshall and Pigou - what I call the destruens part of his approach - on the role played by the assumptions of economic theory. He examined the assumptions that marginal economists had introduced into their theory with the aim of making their tacit assumptions explicit. His methodology shows close similarities to Keynes's criticism of the 
so-called "classical economists" (Carabelli 1991). Sraffa and Keynes sought to understand whether these assumptions were necessary for the theory not to be logically fallacious.

Keynes's criticism of what he called the "classical economists" was of a methodological nature, based on the search for a logical flaw. He set out to make the tacit assumptions of the "classical economists" explicit. The General Theory was addressed to "his fellow economists" and had as its principal object the study of "difficult questions of theory", with the aim of "persuading economists to re-examine critically certain of their basic assumptions" (CW 7, Preface XxI). Keynes's attitude towards the search for tacit assumptions in theories and his attempt to make them explicit, showing the limits to their validity, is the same that emerged in A Treatise on Probability; on this constant attitude, see also Carabelli 1988: 75, 267-268).

Keynes wanted to locate and identify the logical flaw in the classical theory (CW 13: 489). He thought that the relationship between premises and conclusions in the classical theory was perfectly consistent: the superstructure of the classical theory was painstakingly built "for logical consistency" (CW 7: xxI; see also 33, 192). Hence, if the fault of the classical theory lay neither in the empirical unacceptability of the conclusions nor in the logical inconsistency between premises and conclusions, where did it lie? Keynes even went as far as saying that if the basic system of the classical theory was unassailable, then, consistently, one had to accept its conclusions (CW 13: 491). However, the classical system of thought was, he held, assailable, and should be attacked at its heart. The flaw was in the premises of the classical theory, so that the attack should be directed against them, rather than against the conclusions or against the connection between premises and conclusions. The premises lacked 'clearness' (CW 7: xxI; also 33, 192). The classical theory did not make explicit - as it should have done - some assumptions upon which its conclusions rested and upon which its arguments depended for generality and domain of validity.

Keynes's search for the existence of tacit assumptions in the classical theory permeated the whole of his writings. In 1933, in his essay "A Monetary Theory of Production", Keynes wrote of tacit assumptions:

One of the chief causes of confusion lies in the fact that the assumptions of the real-exchange economy have been tacit, and you will search treatises on real-exchange economics in vain for any express statement of the simplifications introduced or for the relationship of its hypothetical conclusions to the facts of the real world (CW 13: 410). 
In 1936, in the General Theory, he wrote: "this strange supposition [...] is what all members of the orthodox school are tacitly assuming [...] the classical school have slipt in an illicit assumption" (CW 7: 13; see also xxv). ${ }^{7}$

\subsection{On Homogeneity}

Sraffa's pre-1928 manuscripts include thorough discussion of the requirements for the measurement of economic quantities, with analysis of both homogeneity and relevance (D1/20 "General", mainly brief notes extracted from books (7 docs.) and "On Economic Quantities: homogeneousness and measurement" (D1/5).

Homogeneity means that there is no difference (or variety) in the kind (or substance) of quantities: "their action is so much different in degree as almost to be a difference in kind" (D3/12/3 Notes London, Summer 1927 Physical Real Costs: 6). In the case of the quantities of labour, of land, of capital and of products, for example, it must be determined whether the respective quantities are homogeneous. The existence of a common standard (a unit of measure) is involved here. In contrast with quantities of labour, land, products, capital and utility, quantities of money are homogenous by definition or convention.

In his search for the requirements of homogeneity, Sraffa not only investigated the assumptions of differences and variety in the substance, but also stressed the assumption of relevant differences or variety. Heterogeneity and variety represented his starting point, so homogeneity was not an intrinsic quality in general, but a logical assumption. Introduction of the assumption of homogeneity depended on judgements of relevance. For Sraffa relevance implied that although there exist differences and variety in the quantities they can be judged negligible: relevance was not empirical but logical, i.e. relevance to the problem under investigation, "relevant (to the problem at hand)", as he wrote. He argued that the difficulty was "to find a criterion for determining the limits" of the assumption of homogeneity when non homogeneous quantities are dealt with in general (D1/5: 1).

For Keynes too, economic quantities are in general non-homogeneous except under restricted conditions which should be investigated. He applied to them his view on probability: probability is a non-homogeneous

7 In 1939, in the Preface to the French Edition of the General Theory, Keynes again stressed the point: "Say was implicitly assuming that [...]" (CW 7: xxxv). Keynes's criticism of Pigou, in the appendix to Chapter 19 of the General Theory, is structured around the search for the existence of tacit assumptions in Pigou's theory (CW 7: 272-275): "Since the tacit assumptions, which govern the application of the analysis, slip in near the outset of his argument, I will summarise his treatment up to the crucial point" (CW 7: 272; see also 274-275 and 277). 
object. Economic magnitudes are "non homogeneous complex which cannot be measured [...] except in certain special cases" (CW 7:38) and "incommensurable collections of miscellaneous objects" (ibid.: 39). Probability is intrinsically a non-precise quantity; the General Theory "vague and non quantitative concepts" (40) are similar to probability. Keynes maintained that probability and the material of probability are, in general, - except in particular limited cases - non homogenous and non atomic: "A degree of probability is not composed of some homogeneous material, and is not apparently divisible into parts of like character with one another" (TP, CW 8: 32). Economic magnitudes and the material of economics are the same.

We will be looking at Sraffa's and Keynes's analysis of the homogeneity of quantities of labour, products, capital, utility and money in detail.

\section{Labour and Products}

In dealing with the measurement of economic quantities, close attention was paid by Sraffa to the criticism made by orthodox economists (Bailey, Sidgwick and Böhm-Bawerk in particular) of the non-homogeneous substance of the quantity of labour and of products. For these economists, the quantity of labour was an ambiguous expression (D1/5: 1). Sraffa also discussed the analogy between measurement of labour and of land (D1/5:7).

In the 1920s Sraffa shared with the critics of the labour theory of value the view that labour was a non-homogeneous quantity, which therefore could not be used as the ultimate standard for the theory of value. As Kurz and Salvadori (2005) argue, he later changed his mind: non-homogeneous quantities of labour can be homogenized.

With respect to the assumption of homogeneity of the quantities of products, Sraffa criticised Marshall's treatment of the varying composition of the dose and variety of products. Marshall introduced in different contexts either a tacit assumption of homogeneity or the money unit (D1/5: 6).

Like the later Sraffa, Keynes argued that labour is a non-homogeneous quantity but that it can easily be made homogenous through a process of reduction. In a well-known passage in the General Theory, Keynes argues his use of the unit of labour as "the sole physical unit" (CW 7: 213-214). He proposed "to make use of only two fundamental units of quantity, namely, quantities of money-value and quantities of employment" (CW 7: 41). Further, "We shall call the unit in which the quantity of employment is measured the labour-unit; and the money-wage of a labour-unit we shall call the wage-unit". The labour-unit can be reduced to a homogenous unit by "taking an hour's employment of ordinary labour as our unit and weighting an hour's employment of special labour in proportion to its remuneration; i.e. an hour of special labour remunerated at double ordinary rates will count 
as two units" (ibid.). The labour-unit provides an unambiguous measure of output; "we shall measure changes in current output by reference to the number of hours of labour paid for (whether to satisfy consumers or to produce fresh capital equipment) on the existing capital equipment, hours of skilled labour being weighted in proportion to their remuneration" (ibid.: 44). He argued that any other units of measurement lead to 'unnecessary perplexity' due to heterogeneity of inputs and outputs.

\section{Capital}

In his early notes made in the 1920s Sraffa also paid close attention to the difficulty involved in the measurement of capital and the role of the assumption of homogeneity of the quantities of capital. Capital is regarded by economists - including Sraffa - as a collection, an aggregate of the most diverse objects. On the theory of capital, Sraffa read Fisher, Cannan and also analysed Marshall's discussion of capital in his Principles (D 1/2; D1/5, pp. 6-7).

Later, on 27 October 1936, in a letter to Joan Robinson, Sraffa explained why he thought the neoclassical theory of capital did not meet the requirements for theoretical measurement:

Many thanks for your letter - it is a valuable addition to my museum and shall hang it next to an extract from Sidgwick where, after lecturing Ricardo on a quantity of labour, he goes on cheerfully himself to talk of quantities of utility.

If one measures labour and land by heads or acres the result has a definite meaning, subject to a margin of error: the margin is wide, but it is a question of degree. On the other hand if you measure capital in tons the result is purely and simply nonsense. How many tons is, e.g., a railway tunnel?

If you are not convinced, try it on someone who has not been entirely debauched by economics. Tell your gardener that a farmer has 200 acres and employs 10 men - will he not have a pretty accurate idea of the quantities of land $\&$ labour? Now tell him that he employs 500 tons of capital, $\&$ he will think you are dotty - (not more so, however, than Sidgwick or Marshall)

(quoted from Bradford and Harcourt 1997: 131)

In his reply to Harrod in the Economic Journal in 1962, Sraffa asked: "what is the good of a quantity of capital [...] which, since it depends on the rate of interest, cannot be used for its traditional purpose [...] to determine the rate of interest?" (Sraffa 1962: 479).

In Keynes's early writings, explicit references to the problems of the measurement of the real stock of capital and to the difficulties of finding a physical unit of capital are hard to come by. Owing to the difficulties in measuring capital, Keynes usually dealt with money capital. Only in 1936, 
in the General Theory, do we find two explicit passages on the measurement of capital, one in Chapter 4 ("the stock of real capital") (CW 7: 37) and one in Chapter 11 ("difficulties as to the definition of the physical unit of capital, which I believe to be both insoluble and unnecessary") (CW 7: 138).

\section{Utility}

On the assumption of homogeneity of the quantities of utility, Sraffa thought that if the quantity of labour was not homogeneous, neither was utility. He noted that if it was 'meaningless' to talk of 'physical real cost', it was 'equally meaningless' to talk of 'psychological real cost', of utility and also of diminishing returns (D1/20 5). Measuring real cost by utility entailed many problems; for example, the heterogeneity of individuals raises difficulties in aggregating their utility (D3/12/3 49).

Keynes's analysis of the measurement and comparison of utility was developed in considerable detail from 1905 onwards. It runs through his 1909 Essay on Index Numbers on to A Treatise on Money and later writings, covering the problems of the non-homogeneity of utility, the non-interpersonal comparison of utility, the measure of the amount of utility which a given sum of money purchases and the non-exact measurement of utility due to organic unities. It is interesting to read Keynes's early comments on the measurement of utility in his 1909 Essay on Index Numbers:

The measure of the amount of utility, which a given sum will purchase, is intrinsically and from the nature of the case beyond our reach. Since the total utility of a commodity is not proportional to its quantity, we have no means of comparison between two different total utilities which are part of differing wholes, and the total utility of a given amount of wealth depends upon its distribution. Even if we know the distribution of wealth, there is no measure of the aggregate of individual utilities. The aggregate exists and is perfectly determinate, but we must not infer from this that two such aggregates can be measured in terms of a common unit. It may be true that there is always a determinate answer to the question as to which of two aggregates of distributed utilities corresponds to the greater amount of total well-being. We are denying, not the existence of such an answer, but the possibility of obtaining it by measuring and applying the formulae of addition to the individuals of the aggregate. There is an aggregate of utilities, we may say, but not a sum.

(CW 11: 59-60)

Later on, in 1930, Keynes reiterated his point of view, in particular examining a number of possible methods of arriving at approximations of the relative purchasing power of incomes, distinguishing between the direct method of comparing incomes of similar persons and various indirect 
methods of comparing prices of equivalent composite commodities. But there were limits to all of these methods:

We are not in a position to weigh the satisfactions for similar persons of Pharaoh's slaves against Fifth Avenue's motor cars, or dear fuel and cheap ice to Laplanders against cheap fuel and dear ice to Hottentots [...]. We cannot hope to find a ratio of equivalent substitution for gladiators against cinemas, or for the conveniences of being able to buy motor cars against the conveniences of being able to buy slaves.

(CW 5: 104-109)

\section{Money, Money Aggregates and Index Numbers}

Money is homogeneous by definition or convention; therefore units of money are homogeneous by themselves. Money is the common standard of measure in economics; problems may arise either in the stability over time of the various price levels, or of the price level, if it exists, or, in the comparability in space and time of the purchasing power. Problems may also arise on the money side or on the side of the commodities under measurement.

Two main difficulties arise in the money measurement of magnitudes: theoretical and practical difficulties. They are commonly addressed with index number theory, in which Sraffa took an interest, as did Keynes, as we will see.

In his pre-1928 manuscripts, Sraffa's search for the requirements of measurement included money, in particular the measure of money value and index numbers. He took notes of Walker's book on money and paid close attention to the Chapter on "Stabilità dell'unità di misura". Sraffa noted that "Il denaro sorge per costume: varie merci-denaro: oro, arg.". Money is "Regolato dalla legge: poi, carta moneta", "Il denaro è una unità di misura, definizione arbitraria dell'unità [stock esistente di oro]” (Sraffa D2/13).

Sraffa argued that Marshall distinguished strictly between 'expenses of production' which are measured in money - giving the money measure of real cost - and real cost: "Expenses of production", reckoned in money, are 'the prices that have to be paid in order to call forth the supply' of those efforts and waitings, and are the money measure of real cost' [D2/ 43 (54)]. Commenting on Pigou's 1927 article "Laws of increasing and diminishing costs", Sraffa noted:

If by real costs P. [Pigou] means expenses of production [...]. Since the reduction to unity is made through their exchange value (and not according to any other, psychological or physical standard) the obvious unit of measure is money (i.e. purchasing power of commodities in general).

(D3/12/ 3 49) 
Sraffa's interest in money also entailed an interest in the value of money and index numbers. Sraffa noted Marx's comment in his History "Sono 'indici"” (D1/9 10). In his pre-1928 "Notes on probability" Sraffa commented on Fisher's unit of measure, pointing out that, like labour, it was variable (D1/49 16). His interest was mainly in the fact that index number theory deals with non-homogeneous complex magnitudes, i.e. composite heterogeneous commodities. Complex magnitudes are incommensurable, apart from some special cases - special cases in which Sraffa was particularly interested. To explain these special cases of complex magnitudes such as the community output, let me quote Keynes's words in the General Theory, "the community's output of goods and services is a non homogeneous complex which cannot be measured, strictly speaking, except in certain special cases, as for example, when all the items of one output are included in the same proportions in another output" (CW 7: 38).

In addition to reading books by Walter and various other authors on money, Sraffa also read Keynes's writings on the subject. In his manuscripts we find a note on an earlier table of contents of Keynes's A Treatise on Money, which seems to be close to the table of contents dated 22 September 1927 (CW 13: 48-50), where Keynes deals with index numbers, weighting and the problem of measurement. Sraffa also read and took notes on Keynes's Tract on Monetary Reform, as well as translating it into Italian. On the other hand, I have no evidence as to whether Sraffa read Keynes's 1909 Essay on Index Numbers, where he first raised the problems of measurement, weighting and proportions. The 1909 essay reappears with changes both in the 1923 Tract on Monetary Reform and in the 1930 Treatise on Money.

Sraffa's analysis of weights and proportions warrants detailed examination since it is at the basis of his Standard commodity. In his pre-1928 "Notes on interdependence and causality" he pointed out:

I may be measuring a group of quantities without knowing their identity, i.e. when I measure another group of quantities, that are really distinct from them, but within a certain range are appreciably proportional to them: within these limits the theory holds good, but it is bound to be falsified when the two groups become differentiated, disagree and move independently of one another. This is very common in economics.

(D1/9 10)

In his "Notes on language", in dealing with the rate of wage, Sraffa argued that "the definitions of the rate of wages and rate of interest are similar in many respects, and different in one". Sraffa's stress on their difference more than on their similarities is relevant here: "The difference is that rate of interest is 'money per unit of money'; rate of wages 'commodity 
per unit of man'”. Hence the dimensions of money and rate of wage are different. He concluded:

It is necessary to reduce the two rates to a common basis. This can be done by regarding all the quantities concerned in both rates as quantities of labour. In order to do this however we must first be able to measure the quantities of capital and of product concerned in terms of labour. This may be done provided we assume that the total price of the aggregate of commodities that compose wages is made up in the same proportion of wages and profits as the total price of the aggregate of commodities that compose profits.

(D $3 / 12 / 7$ 141)

Sraffa, therefore, deemed it necessary to introduce the assumption that the two aggregates of commodities were made up in the same proportion of wages and profits to reduce them to a common basis. On 13 and 19 February 1931, dealing with capital and the standard chosen for measuring the value of capital, Sraffa came back to the weights and proportions argument, as regards 'the value of a mass of articles' and the value of non proportional quantities. He explicitly referred to the problem of weights in index numbers:

The problem turns entirely upon the standard chosen for measuring the value of capital [...]. Since the inquiry is on the rate of interest (five per cent), the measure must be such as to equate the "five" (consumption goods) with the "cent" (capital); therefore capital must be evaluated in terms of consumption goods. The unit of measure is a parcel of cons. goods, combined in the same proportions as they are produced: these proportions are assumed not to vary; and each capitalist and each worker consumes them in these proportions: no saving takes place.

The problem of measuring the value of a mass of articles is identical with that of an index No of prices: only, the weights are automatically determined by the quantity of each article [...]. Consequently, the two total values (or index numbers), being differently weighted, will not vary proportionally when wages are raised.

(D $3 / 12 / 7 / 1573,4)$

On 22 July 1931, commenting on Keynes's distinction between fixed and circulating capital in his Treatise on Money and on his "way of regarding machines as a factor of production which has nothing to do with circulating capital", Sraffa then concluded that "It also amounts to acknowledging that capital is really only measurable in terms of value. Marshall (however muddled) as opposed to Böhm Bawerk was not so wrong after all. Nor were Ricardo, Marx, etc. who always measured capital in money" (D3/12/7/ 159). In 1932, the problem of weighting also underlay the discussion with Hayek: 
For each possible index number of price (i.e. the price of composite commodity) there is a rate of interest on money which, if adopted by the banks (who lend freely at it) will keep it stable: each rate is an average of rates on the various commodities included in the index number, at any one moment, weighted as they are in the index number.

(D3/9 7)

Sraffa continued to work on the hypothesis of balanced proportions in the 1940s. In his notes dated from 23.1.44 to 20.3.44 (D3/12/36) he worked on the Standard system equations. His hypothesis was to assume that the proportions between the sum of the inputs of each commodity and of output of the same commodity be equal in all the commodities. He called this hypothesis 'statistical'. In his Note 70 he stressed that the elements of the reduction to dated quantities of labour: "are in constant proportions, such that the ratio of any one of them to the sum of all preceding ones (i.e. to the left of it) is R". Sraffa's 1960 standard commodity is a composite commodity, with 'balanced' proportions; that is, with the same proportions in all its 'layers': "The 'balanced' commodity which we have just considered (\$21) would present no peculiarities of this type, since the same proportion would be found in all its 'layers'” (Sraffa 1960: 18).

Keynes's views on the measurement of the value of money, and of other complex economic magnitudes in general, were formulated in considerable complexity over a long period of time. There is nothing new in Keynes's approach to complex magnitudes and their units of quantity and measure as found in Chapter 4 of the General Theory. He had already considered them in at least five of his previous writings: in 1905, in his papers on index numbers written for Marshall, in 1907, in the first version of his Dissertation The Principles of Probability (later A Treatise on Probability) whilst considering the measurement of the relation of probability; in his 1909 Essay on Index Numbers while considering the measurement of price level, in his analysis of the price level in the Tract on Monetary Reform (1923) and in A Treatise on Money (1930) (see Carabelli 1992). Central to his thought is the problem of weighting and proportions (CW 11: 72-94; CW 5: Chap. 4 and Chap. 8).

\subsection{On Independence}

Sraffa paid close attention to the notions of independence, interdependence and causality (D1/9). Dependence means that some type of causality is implied, but there is no agreement in philosophy and in the history of thought on what causality means. On this topic, Sraffa's readings were De Quincey on 'Malthus on the measure of value', Pigou's Economics of 
Welfare and his 1913 article on 'The interdependence of different sources of demand and supply in a market', Wicksteed's Common Sense, Sidgwick's Principles and Keynes's A Treatise on Probability (1921).

Sraffa's criticism of partial equilibrium theory was based on making explicit the assumption of mutual independence of the demand and supply curves of products. The argument that in economic theory nothing was to be clarified as regards the theory of value had, he observed, already been stated by John Stuart Mill in 1849, Pantaleoni in his obituary of Pareto and John Maynard Keynes in his 1923 Introduction to Cambridge Economic Handbooks. Sraffa was of the contrary opinion. He stressed that for the economic theory of partial equilibria the hypothesis of independence was a necessary condition for it to hold in terms of logic without falling into fallacies. In particular, he went on, the theory of partial equilibria required that the demand and the supply curves be mutually independent (D1/20 7).

In his Notes on Marshall's condition "Other things being equal" in Principles of Economics ( $8^{\text {th }}$ edition) dated April 1923, Sraffa stressed that this is not one condition, but many conditions, or rather infinite conditions (D 1/2). In his 1928-1931 advanced lectures, while discussing partial and general equilibrium, Sraffa noted that the tacit ('concealed') assumption of independence had to be introduced: prices and quantities of all the other commodities do not remain unchanged [D2/ 43 (84)]. In particular, when dealing with the production as a whole, the assumption of independence may give rise to logical fallacies; for example, the demand for corn is not independent of variation in national income (D1/22 17).

Sraffa also analysed "the conditions in which the "existence of substitutes' blows up every economic theory", because it means that there is interdependence between commodities (D1/20 5). Marshall's "exceptional cases" were the target of his investigation. Exceptions "are the rule" (D1/22/1). On the interdependence of demand curves, Sraffa noted that Wicksteed and Cairnes had already raised the question of the interdependence of supply and demand curves [D2/ 4 21(3); D2/ 4 24; D1/ 22 11].

Sraffa's discussion of the interdependence of commodities, prices and demand and supply is to be associated with his interest in general economic equilibrium. In his "Lecture notes on economic theory" Sraffa asked what economic theory actually was, and argued that reality was extremely complex and the price of each commodity was influenced by the prices of all other commodities, concluding that to know the causes of the price of a commodity would require so much knowledge as to fill 10.000 books beyond the realm of possibility (D2/1 1). On this topic, Sraffa referred to Walras', Pareto's and Cassel's theories of general equilibrium, with Cassel's version considered inferior [D2/ 4 4(3), 5(6)]. 
Keynes took great care in detecting the different nature of the tacit assumptions of independence in classical theory. The various assumptions he considered can be classified in three types:

- the assumption of independence from changes in the value of money;

- the assumption of independence from changes in the value of output and unemployment;

- the assumption of independence from changes in the level of income.

The assumption of independence from changes in the value of money carried with it the idea of neutral money and allowed the classical theoretician to pass, without any change in reasoning, from a real exchange economy to a money economy, and brought with it the false analogy between the two. Hence, truly and consistently, under this assumption a money economy was equal to a real economy. According to Keynes, the assumption took on different forms within the classical theory: that of neutral money, that of a uniform purchasing power of money (as if money were a 'mean sum') and that of neglecting possible changes in the general purchasing power of money.

Keynes took Marshall's and Pigou's writings into consideration with regard to this type of assumption. Marshall, he observed, supported Cournot's assumption of a standard of uniform purchasing power (CW 13: 409). As regards Pigou, Keynes referred to his introduction of the tacit assumption that the supply of labour was independent of changes in the value of money (CW 13: 409-410).

The assumption of independence from changes in the value of output and unemployment implied that the economic system was operating to its full capacity, which meant an independence from the level of output or employment. According to the classical theory, introduction of the assumption allowed for straightforward transition from argumentation based upon a full-capacity economy to argumentation based upon a situation characterized by unemployment. In the Preface to the French Edition of the General Theory, Keynes suggested that the use of Say's basic assumptions, such as that demand is created by supply, meant independence from the level of output (CW 7: xxxII-xxxiIr; see also p. 21 and CW 13: 278).

This was the ground for Keynes's criticism that the classical saving and investment schedules could not 'shift independently of one another' and that there was interdependence between the two (CW 7: 179). Similarly, supply and demand curves for loanable funds were not independent. One 'could not obtain a determinate conclusion without introducing some additional equation or datum' (CW 29: 228). Keynes linked the interdependence of supply and demand with his money theory of value (CW 7: XXII-XXIII). 
In comparison with Sraffa's methodological attitude, it is also interesting to note Keynes's methodology of criticism in his A Tract on Monetary Reform, a book well known to Sraffa. In fact, a very similar criticism based on the introduction of tacit assumptions of independence had already been raised by Keynes against the quantity theory of money in his Tract on Monetary Reform (1923):

the [quantity] theory has often been expounded on the further assumption that a mere change in the quantity of the currency cannot affect $\mathrm{k}, \mathrm{r}$, and $\mathrm{k}^{\mathrm{*}}$ - that is to say, in mathematical parlance, that $\mathrm{n}$ is an independent variable in relation to these quantities. It would follow from this that an arbitrary doubling of $n$, since this in itself is assumed not to affect $\mathrm{k}, \mathrm{r}$, and k', must have the effect of raising $\mathrm{p}$ to double what it would have been otherwise ... Now "in the long run" this is probably true $[\ldots]$ But this long run is a misleading guide to current affairs. In the long run we are all dead $[\ldots]$ In actual experience, a change of $\mathrm{n}$ is liable to have a reaction both on $\mathrm{k}$ and $\mathrm{k}$ ' and on $\mathrm{r}$.

(CW 4: 65)

In similar vein were Keynes's criticisms of the theory of purchasing power parity ("the theory requires a further assumption for its validity") and the presumed intrinsic stability of the value of gold ("The independent variety of the influences determining the value of gold has been in itself a steadying influence $[. .$.$] The value of gold is no longer the resultant$ of the chance gifts of nature and the judgement of numerous authorities and individuals acting independently") (CW 4: 75, 133-134). In A Treatise on Money (1930), the point was reiterated by Keynes: "the purpose of isolating 'changes on the side of money"'; "subject to 'independent' influences"; "the non-independence of relative price changes" (CW 5: 73, 75, 77).

\section{Sraffa’s versus Keynes's Constructive Approach}

Having discussed the similarities between Sraffa and Keynes's critical approaches to economic theory based on the assumption of homogeneity in the quantities of labour, products, capital, utility and money, and on the role played by the assumption of logical independence, let us now consider their constructive approaches. Here they move in opposite directions, along with their contrasting choices of magnitudes to be considered in economics. Sraffa, in his constructive approach, sought for an absolute physical standard of value and measure, while Keynes stuck to money measures and to the unit of labour as the sole physical unit. 
Sraffa on the theory of value. Real costs: disutility or physical real cost?

In theory of value Sraffa searched for the ultimate standard of value and defended cost as physical real cost against disutility. He noted that, according to economists such as Marshall, Clark, Scharling and Böhm Bawerk, real cost is "an aggregate of the unpleasant feelings of various sorts felt by the individuals connected with production" (D2/4 3 (21)) and that "All the ultimate standards we have considered up to the point are psychological [...] Real costs interpreted as disutility” (D3/12/3 42; see also D1/22 5-6).

In his analysis of Marshall's theory of value - called by him the "single theory of value" - Sraffa held that the fundamental step made by Marshall was the reduction of cost to a quantity of disutility [D2/ $43(18,20-21)]$. Two heterogeneous quantities were reduced to a common homogeneous one (D1/28 2-3; D1/30). In this way Marshall was able to bring together two quantities, utility and disutility, which are heterogeneous - not of "the same kind", as Sraffa wrote [D2/4 3 (66)] - to a homogeneous quantity: disutility was made of "the same nature" as utility. By reducing cost to a common measure based on utility Marshall was able to take it as a negative magnitude which could be "added or subtracted and balanced against one another" [D2/ 43 (17)]; thus the laws of addition and subtraction and the idea of a common balance on which to weight cost and utility could be applied. Sraffa pointed out the central role that the measurement of motives played in Marshall's method and theory of value [D2/4 3 (22)]. Marshall's use of symmetry in economic theory and his idea of the scissor theory of value rested, then, on the tacit hypothesis of the homogeneous nature of quantities.

\section{Sraffa's Search for a Physical Unit of Measure: Food rather than Labour?}

Sraffa aimed at a theory of cost which was grounded on physical terms, a real physical costs theory. As we have seen, he held that utility could not be a common standard: the psychological standard was to be rejected. He was interested in searching for a common physical unit of quantity and a common physical standard of measure: "we must find some ultimate standard, independent from the variables we are considering, such [as] utility, disutility or labour" (D3/12/ 3 Notes London, Summer 1927 Physical Real Costs, p. 13).

The quantity of labour was inadequate because it was not homogenous; money as measure carried for Sraffa a flavour of utility. Even less was he interested in the money wage of labour. In the Ricardo-Malthus controversy, Sraffa sided with Ricardo, defending Ricardo's labour theory of value against Malthus's theory based on the money wages received by labour (D3/12/3 47; D/3/12/4). 
Petty's theory of physical quantities was Sraffa's benchmark. Petty's common measure of value was "the days food of an adult Man". A theory of cost which was "concrete, tangible and visible", that could "be measured in tons or gallons". It was the opposite of Marshall's cost, which was individually based, and could only be measured in money terms. Sraffa quoted, with approbation, Petty's well known passage in his preface to Political Arithmetick (Petty 1670, I: 244):

The method [...] to express my self in terms of Number, Weight or Measure; to use only Argument of sense, and to consider only such Causes, as have visible foundation in Nature; leaving those that depend upon the mutable Minds, Opinions, Appetites and Passions of particular Men to the Consideration of others.

[Sraffa D2/ $43(21)]$

Sraffa's aim was to find an absolutely necessary commodity; this necessary commodity represents one of the bases of his 1960 Production of Commodities by Means of Commodities. Was corn this ideal and absolutely necessary commodity? In the history of economic thought economists went "from food to labour". Sraffa thought "The right notion of cost as 'loaf of bread'. Then somebody started measuring it in labour, as every day's labour requires the same amount of food" (D/3/12/4 Nov. 1927). His answer to the question whether corn is that necessary commodity, was negative. Corn was not:

an absolutely necessary commodity found, the difficulty of reducing to a common measure the various things entering into real cost would solve by itself $[\ldots]$ by going back enough in the genealogy of production [...] we might find exactly the total amount of corn (if this were the ideal necessary commodity which is not).

(D3/12/ 344$)$

Rather than corn, "the objective, physical, necessaries of existence" consisted in the amount of various commodities:

we must find a unit of measure for cost: the necessity for this unit arises, not from a desire of actually measuring, - it is prior to it, and is required even for thinking of cost. The best measure available is the amount of various commodities that is required to support during an hour a average labourer [...] the amount of necessaries.

(D3/12/3 46) 
Sraffa's Question: Is There Any Real Need for a Common Natural/Physical Unit of Measure?

In his pre-1928 notes Sraffa raised the question as to whether physical aggregate quantities - always and in general - require a common unit of measure and standard. This seemed to be indispensable for defining real costs. But, as we will see, this was not what Sraffa thought. He quoted and commented on Sidgwick on the necessity of a common standard for the conception itself of physical real costs. In contrast with Sidgwick, Sraffa thought that, under limited conditions, there is no need to have a common natural/physical unit of measure:

Some of the most eminent (economists) have not always seen that it is impossible to think definitely of the quantity of an aggregate of diverse elements, except so far as these elements admit of being reduced to a common quantitative standard, and that unless this is done, when we speak of such an aggregate having increased or decreased in amount, or of something else varying "in proportion to" it, we are using word to which there are necessarily no definite thoughts corresponding.

Sraffa commented on Sidgwick:

The first sentence seems right, but the second wrong. The conception of physical real costs, the replacement of exactly those things that have been used in production, is a clear and definite conception and does not require a "common standard". This necessity of a "common standard" is a prejudice: if we don't vary the quantity, or if we vary the physical quantity of all elements in the same proportion, no common unit is required.

$(\mathrm{D} 1 / 22$ 10)

He advanced the idea - which we now know underlies his interpretation of Ricardo's theory of profits (Sraffa 1951) and the main assumptions of his Production of Commodities by Means of Commodities (1960), that if the quantities do not vary or if the quantities of all elements vary in the same proportion, no common unit or standard is required. In Sraffa's interpretation of Ricardo's corn model, there is no problem of aggregation of heterogeneous commodities, corn being the only commodity; therefore homogeneity is assumed by definition. When there are many commodities (two commodities are enough), if the quantities do not vary (or if they are kept constant by assumption) or if the quantities vary in the same proportion in the two aggregates under consideration or comparison; or if the quantities of the numerator and of the denominator are in the same proportion, it is as if there is homogeneity. In his Production of Commodities by Means of 
Commodities (1960) the hypothesis that quantities do not vary is explicitly present; and the "standard commodity" shows proportional variations in the quantities of commodities:

The 'balanced' commodity which we have just considered $(\S 21)$ would present no peculiarities of this type, since the same proportion would be found in all its 'layers'. It is true that, as wages fell, such a commodity would be no less susceptible than any other to rise or fall in price relative to other individual commodities; but we should know for certain that any such fluctuation would originate exclusively in the peculiarities of production of the commodity which was being compared with it, and not in its own. If we could discover such a commodity we should therefore be in possession of a standard capable of isolating the pricemovements of any other product so that they could be observed as in a vacuum.

(Sraffa 1960: 18)

Particular proportions, such as the Standard ones, may give transparency to a system and render visible what was hidden, but they cannot alter its mathematical properties (Sraffa 1960: 23)

Sraffa's idea that if the quantities do not vary or if the quantities of all elements vary in the same proportion, no common unit or standard is required, seems to me to have been borrowed from index numbers analysis and applied to the theory of prices and distribution. As seen in the section on money, Sraffa was interested in index number theory. In this latter theory, "the community's output of goods and services is a non homogeneous complex which cannot be measured, strictly speaking, except in certain special cases, as for example when all the items of one output are included in the same proportions in another output" (CW 7:38). The special case is Sraffa's case, a case which Keynes did not like.

\section{Keynes's Monetary Standard and His Money Theory of Value}

In the General Theory, Keynes argues that the choice of units was one of "the three perplexities which most impeded my progress in writing this book, so that I could not express myself conveniently until I had found some solution for them" (CW 7:37). The central concepts and magnitudes involved in his analysis are complex. These concepts are the volume of real output/income, the volume of real net output, the stock of real capital, aggregate goods and services and the general price level (ibidem). Keynes defines them as "incommensurable collections of miscellaneous objects" (ibid.: 39). In particular, "the community's output of goods and services" is "a non-homogeneous complex which cannot be measured" (ibid.: 38). In the General Theory there is also another complex magnitude, that of probability. Keynes considers probability separately in chapters 5 and 12. For Keynes, 
these concepts are theoretically vague. He refers to "the well-known [...] element of vagueness which [...] attends the concept of the general price level" (ibid.: 39). Theoretical vagueness does not mean that these logically indefinable concepts are also vague and ambiguous from an ordinary language point of view or in business practice. In ordinary language their meaning is easily grasped and they can be used for practical purposes.

Complex magnitudes are indefinable in logical terms since it is impossible to reduce them to more simple terms. They cannot be reduced to simple terms without falling into logical fallacies and paradoxes. The fallacy of composition is well known to economists. Complex magnitudes also possess attributes which belong to different dimensional scales. They are multidimensional magnitudes, inasmuch as they can move simultaneously in more than one direction. This calls for a theory of the units of quantities appropriate to them and it also means having an appropriate theory of measurement. For Keynes, complex magnitudes are theoretically troublesome as far as measurement is concerned. They raise logical "conundrums" rather than mathematical or statistical difficulties (CW 7: 39). The classical economists had committed logical errors by ignoring this problem: "the units, in terms of which economists commonly work, are unsatisfactory" (ibid.: 37). Being non-numerical quantitative concepts (ibid.: 40), the quantities of real output, real net output, real capital, aggregate goods and services and the general price level do not exist, any more than do absolute and homogeneous units of measure appropriate to these quantities. For this reason Keynes stated that complex concepts "cannot in themselves provide the material for a quantitative analysis" (ibid.: 39). Thus, the endeavour by classical economists "to erect a quantitative science" (ibid.: 38) upon these concepts was a logical failure. The outcome was "a mock precision", as it tried "to use such partly vague and non-quantitative concepts as the basis of a quantitative analysis" (ibid.: 40). As a result, he wrote:

It is my belief that much unnecessary perplexity can be avoided if we limit ourselves strictly to the units, money and labour, when we are dealing with the behaviour of the economic system as a whole; reserving the use of units of particular outputs and equipments to the occasions when we are analysing the output of individual firms or industries in isolation; and the use of vague concepts, such as the quantity of capital equipment as a whole and the general level of prices, to the occasions when we are attempting some historical comparison which is within certain (perhaps fairly wide) limits avowedly unprecise and approximate.

(CW 7: 43)

For Keynes, money is the only standard and unit of measure. Economic magnitudes are not "concrete, tangible and visible"; they cannot be "physi- 
cally measured, in number, weight (tons or gallons)", as Sraffa required. Furthermore, as "psychological uncertainties", they are not directly observable (CW 14: 300). The hypothesis of "equal proportions" cannot be applied as quantities change in a non proportional way.

\section{Conclusions}

The main focus of this paper has been on measurement in economics. I have investigated two authors, Sraffa and Keynes, who were in close contact in Cambridge in the 1920s and 1930s, but for whom at least up to now we have no methodological comparisons.

We have seen that there are significant similarities between Sraffa's and Keynes's methodologies of critique, the so-called pars destruens of their thought, based on making explicit the logical tacit assumptions in the economic theory under attack. Two tacit assumptions are fundamental here with respect to measurement: the assumption of homogeneity in kind and logical independence. Both Sraffa and Keynes accepted that economics is characterized by heterogeneity and variety; both believed that the material of economics is complex and interdependent and require a theory and concepts with similar characteristics. Both believed that investigation into measurement is necessary for the purpose of conceptual reasoning rather than for actual measurement.

A conclusion drawn by this paper is that, in Sraffa's development of the standard commodity, a central role is played by the assumption of "equal proportions" between components or layers - a hypothesis he seems to have borrowed from index number theory, and which is connected with the problem of weighting. When quantities do not change or when they change in the same proportions between two complex aggregates under measurement or comparison, we do not need a common unit of measure. Sraffa began by searching for a physical measure, a commodity. Initially it was corn rather than labour, labour not being homogeneous. Subsequently he moved towards a hypothetical composite commodity which showed equal proportions - an abstract commodity necessary at the conceptual level and to understand what happens in economic reality, without actually picturing it.

Notwithstanding these striking similarities, the differences between Sraffa and Keynes in their constructive approaches were considerable. They showed contrasting attitudes in the pars construens of their economic theory: Sraffa moved towards an objectivisation of economic theory based on physicalism and empiricism, while Keynes always remained faithful to a money vision of the economy which opposes physicalism and empiricism 
and defends a weak form of rationalism, stressing that some economic magnitudes are intrinsically non-measurable, but that this precluded neither work on economic theory nor justification of economic intervention. Money measures were inevitable. For Sraffa, on the contrary, physical measurement was still necessary and possible.

\section{REFERENCES}

BeLlofiore R. and CARTER S. (eds.) 2014, Towards a New Understanding of Sraffa: Insight from Archival Research, Basingstoke: Palgrave Macmillan.

Blankenburg S., Arena R. and Wilkinson F. 2012, "Piero Sraffa and 'The True Object of Economics': The Role of the Unpublished Manuscripts", Cambridge Journal of Economics, Special Issue: New Perspectives on the Work of Piero Sraffa, 36 (6): 1267-1290.

Bradford W. and Harcourt G.C. 1997, "Units and Definitions", in G.C. Harcourt and D.A. Riach (eds.), A Second Edition of the General Theory, vol. 1, London: Routledge: 107-131.

Bridgman P.W. 1927, The Logic of Modern Physics, New York: Macmillan.

Carabelli A. 2003, "Keynes: Economics as a Branch of Probable Logic", in J. Runde and S. Mizuhara (eds.), The Philosophy of Keynes's Economics, London: Routledge: 216-226.

- 1995, "Uncertainty and Measurement in Keynes: Probability and Organicness", in S. Dow and J. Hillard (eds.), Keynes, Knowledge and Uncertainty, Aldershot: Elgar 137-160.

- 1994, "Keynes on Mensuration and Comparison", in K. Vaugh (ed.), Perspectives on the History of Economic Thought, Aldershot: Elgar 204-238.

- 1992, "Organic Interdependence and Keynes's Choice of Units in the General Theory", in B. Gerrard and J. Hillard (eds.), The Philosophy and Economics of J.M. Keynes, Aldershot: Elgar: 3-31.

- 1991, "The Methodology of the Critique of the Classical Theory: Keynes on Organic Interdependence", in B. Bateman and J. Davis (eds.), Keynes and Philosophy, Aldershot: Elgar: 104-125.

- 1988, On Keynes's Method, London: Macmillan.

Chiodi G. and DitTa L. 2013, "Sraffa and Keynes: Two Ways of Making a 'Revolution' in Economic Theory", in E.S. Levrero, A. Palumbo and A. Stirati (eds.), Sraffa and the Reconstructon of Economic Theory, vol. 1, London: Macmillan: 218-240.

- 2010, Sraffa or an Alternative Economics, London: Macmillan.

Ciccone R., Gerhrke C. and Mongiovi G. (eds.) 2011, Sraffa and Modern Economics, New York: Routledge.

Davis J. 2018, "Sraffa on the Open vs. 'Closed Systems' Distinction and Causality", Research in the History of Economic Thought and Methodology, 35B: 153-170.

Eddington A.S. 1928, The Nature of the Physical World, Cambridge: Cambridge University Press.

Hertz H. 1899, Principles of Mechanics, London: Macmillan.

Keynes J.M. 1972-1989, The Collected Writings of John Maynard Keynes, ed. by E. Johnson and D. Moggridge, London: Macmillan (CW): 
vol. 7. The General Theory of Employment, Interest and Money [1936], 1973;

vol. 8. A Treatise on Probability [1921], 1973;

vol. 13. The General Theory and After: Part I. Preparation, 1973;

vol. 14. The General Theory and After: Part II, Defence and Development, 1973.

- 1908, The Principles of Probability, submitted as Fellowship Dissertation to King's College, Cambridge in Dec. 1908; Keynes MSS, King's College Library, Cambridge.

- 1907, The Principles of Probability, submitted as Fellowship Dissertation to King's College, Cambridge in Dec. 1907; Keynes MSS, King's College Library, Cambridge.

Knight F.H. 1924, 'The Limitations of Scientific Method in Economics', in Tugwell 1925.

Kurz H.D. 1998, "Against the Current: Sraffa's Unpublished Manuscripts and the History of Economic Thought", European Journal of the History of Economic Thought, 5: 437-451.

Kurz H.D. and SAlvadori N. 2005a, "Removing an 'Insuperable Obstacle' in the Way of an Objectivist Analysis: Sraffa's Attempts at Fixed Capital”, European Journal of the History of Economic Thought, 12: 493-523.

- 2005b, "Representing the Production and Circulation of Commodities in Material Terms: On Sraffa's Objectivism", Review of Political Economy, 17: 413-441. Reprinted in H. Kurz, L. Pasinetti, and N. Salvadori (eds.), Piero Sraffa: The Man and the Scholar, London: Routledge: 249-277.

- 2004, “Man from the Moon'. On Sraffa's Objectivism”, Economies et Societies, 35: 1545-1557.

- 1998, "Given Quantities", in H.D. Kurz and N. Salvadori (eds.), The Elgar Companion to Classical Economics, vol. I, Cheltenham: Edward Elgar.

Marshall A. 1920, Principles of Economics, $8^{\text {th }}$ ed., London: Macmillan.

Lutz F. and Hague D.C. (eds.) 1961, The Theory of Capital, London: Macmillan.

PetTy W. 1899 [1691], "Political Arithmetick”, in W. Petty, The Economic Writings of Sir William Petty, vols. I-II (C.H. Hull ed.), Cambridge: Cambridge University Press.

Ricardo D. 1951-1973, The Works and Correspondence of David Ricardo, vols. I-XI (ed. by P. Sraffa with the collaboration of M.H. Dobb), Cambridge: Cambridge University Press.

Signorino R. 2001a, "An Appraisal of Piero Sraffa's 'The Laws of Returns under Competitive Conditions'”, European Journal of the History of Economic Thought, 8: 230-250.

- 2001b, "Piero Sraffa on Utility and the Subjective Method in the 1920s: A Tentative Appraisal of Sraffa's Unpublished Manuscripts", Cambridge Journal of Economics, 25: 749-763.

- 2000a, "Method and Analysis in Piero Sraffa's 1925 Critique of Marshallian economics", European Journal of the History of Economic Thought, 7: 569-594.

- 2000b, "The Italian Debate on Marshallian (and Paretian) Economics and the Intellectual Roots of Piero Sraffa's 'Sulle relazioni fra costo e quantità prodotta'. A note”, History of Economic Ideas, 8: 143-157.

Sraffa P. 1962, "Production of Commodities: A Comment", Economic Journal, LXXII: 477-479.

- 1960, Production of Commodities by Means of Commodities. Prelude to a Critique of Economic Theory, Cambridge: Cambridge University Press. Italian ed.: Produzione di merci a mezzo di merci. Premesse a una critica della teoria economica, Torino: Einaudi.

- 1951, Introduction to Ricardo's Works, Cambridge: Cambridge University Press. 
- 1932, “Dr. Hayek on Money and Capital”, Economic Journal, 42: 42-53.

- 1931, Surplus Product, D3/12/7 161: August 1-5. Sraffa MSS, Wren Library, Trinity College, Cambridge.

- 1930, “A Criticism' and 'Rejoinder'”, (contributions to the Symposium on 'Increasing Returns and the Representative Firm'), Economic Journal, 40: 89-93.

- 1926, "The Laws of Returns under Competitive Conditions", Economic Journal, 36: 535-550.

-1925, "Sulle relazioni fra costo e quantità prodotta", Annali di Economia, 2: 277-328; English translation in L.L. Pasinetti (ed.) 1998, Italian Economic Papers, vol. III, Bologna: Il Mulino and Oxford: Oxford University Press.

Tugwell R.G. (ed.) 1924, The Trend of Economics, New York: Alfred A. Knopf.

Whitehead A.N. 1926, Science and the Modern World, Cambridge: Cambridge University Press.

Whyte L.L. 1928, Archimedes or The Future of Physics, London: Kegan, Paul, Trench, Trubner \& Co. 